Marcin J. Leszczyński

Uniwersytet Łódzki

\title{
Krytyka myślenia mito-logicznego: przypadek Pierre’a Legendre’a
}

Mit wydaje się pojęciem zadomowionym w filozofii, ale tylko warunkowo. Oznacza stan myśli przedkrytyczny, przedfilozoficzny i przednaukowy wreszcie. W mity wierzyli starożytni, teraz wierzą w nie dzieci i ludy prymitywne. Mity próbują tłumaczyć rzeczywistość, ale robią to w sposób naiwny i błędny. Naiwny, bo nie potrafią powiązać zjawisk w ciąg kauzalny, nie tłumaczą właściwie stojącego za nimi mechanizmu. Ich fałszywość wynika ponadto $\mathrm{z}$ powszechnego przekonania o istnieniu sił nadprzyrodzonych, transcendujących naszą rzeczywistość, które są zasadniczą przyczyną zjawisk.

Mit stanowi dla filozofii przeszkodę. Mity rozumie się jako przejawy zdrowego rozsądku, pozbawione odpowiedniej dozy krytycyzmu i konieczności empirycznej weryfikacji. Dla nauki mogą stanowić punkt wyjścia (często tak jest ${ }^{1}$ ), po to, by w końcu stać się przedmiotem badań. Wreszcie pod potocznym rozumieniem mitu odnajdziemy niegdysiejsze przekonania ułożone w opowieści, w których występują postaci o mocach nadprzyrodzonych. Zbiory tych opowieści to mitologie. Tak przedstawia się wąskie, literackie rozumienie mitu. Inne jego słownikowe pojęcie zbliżone jest do wspomnianego „zdrowego rozsądku”, który może przyjmować wiele różnych znaczeń. Nie chodzi tu bynajmniej o jakąś teorię

${ }^{1}$ Alchemia oparta była na mitologii hermetycznej i założeniach, które nie umożliwiały wyłonienia się z niej nauki. Z drugiej strony alchemicy stworzyli podwaliny pracy laboratoryjnej i byli w stanie przeprowadzić nawet skomplikowane reakcje. Zob. R. Bugaj, Hermetyzm, Wrocław 1991. 
zdrowego rozsądku, ale raczej o pewne przekonania o świecie, które podziela wiele osób ${ }^{2}$.

Z filozoficznego punktu widzenia, który zasadniczo jest spojrzeniem analizującym pojęcia w odróżnieniu od li tylko ustalania znaczeń ${ }^{3}$, mit może inkorporować wiele innych elementów: emblematy, alegorie, symbole ${ }^{4}$. Ujawnia nam się wtedy pewna funkcja mitu wobec innych opowieści czy znaków, ale też jego swoista struktura. Struktura może dotyczyć jego treści, co prowadzi do wniosków o powtarzalnej wśród różnych społeczeństw strukturze narracyjnej czy treściowej ${ }^{5}$. Jeśli jednak przyjmiemy szersze rozumienie mitu, które mogłoby być tożsame po prostu z myśleniem potocznym, niekrytycznym, wtedy „myślenie” mitem oznacza przyjmowanie za pewne tez, które nie są poparte doświadczeniem bądź nie mogą nim być poparte. Mimo to, w lepszym lub gorszym samopoczuciu, mity te dalej wyznajemy.

W takim wydaniu mity znaleźć można zatem i w filozofii. Leszek Kołakowski w swej książce Obecność mitu przeprowadził wielopłaszczyznową krytykę różnych racjonalistycznych przeświadczeń zdroworozsądkowych, jak i filozoficznych. Celem tej krytyki było ukazanie sfery ludzkiej, mówiąc bardzo ogólnie, egzystencji, którą Kołakowski utożsamił wprost z różnymi formami wartościowania. „Wszystkie racje - powiada - w których zakorzeniona jest świadomość mityczna, zarówno w odmianie wyjściowej,

${ }^{2}$ Dobrym przykładem takiego rozumienia mitujest nastawienie naturalne, analizowane przez Husserla w Ideach I. W owym naturalnym nastawieniu znajdujemy się my wszyscy i spoglądamy na świat wedle naszych przyzwyczajeń. Fenomenologia byłaby metodą wyjścia poza perspektywę zdrowego rozsądku.

${ }^{3}$ G. Deleuze, F. Guattari, Co to jest filozofia?, przeł. P. Pieniążek, Gdańsk 2000, s. 9, 21-23.

${ }^{4}$ G. Durand, Wyobraźnia symboliczna, przeł. C. Rowiński, Warszawa 1986, s. 22. Należy tu zaznaczyć, że dla Duranda to symbol jest kategorią, która najpełniej wyraża wieloznaczności, próby tłumaczenia czy prostego oznaczania, również tego, co niewyrażalne czy wręcz transcendentne.

${ }^{5}$ C. Lévi-Strauss, Antropologia strukturalna, przeł. K. Pomian, Warszawa 2000, s. 189. 
jak i w przedłużeniach metafizycznych, są tedy aktami afirmacji wartości”.

Owa świadomość mityczna ujawnia się, po pierwsze, w sferze poznania, również naukowego, pod postacią przekonania o niezapośredniczonym dostępie do świata zewnętrznego i aksjologicznej neutralności tego aktu. Kołakowski podał pewnego rodzaju definicję tego szerokiego rozumienia mitu:

Nazywam mitycznym wszelkie przeświadczenie, które nie tylko w tym znaczeniu transcenduje skończone doświadczenie, iż nie jest jego opisem (bo każda hipoteza w tym znaczeniu poza doświadczenie wykracza), lecz w tym także, że relatywizuje wszelkie możliwe doświadczenie, odnosząc je rozumiejąco do realności zasadniczo niezdolnych do tego, aby ich słowne opisanie weszło w więź logiczną z opisaniem słownym doświadczenia ${ }^{7}$.

Mówi się tu o poznaniu, które nie może zostać ograniczone do doświadczenia, ale również o tym, że samo to doświadczenie podlega daleko idącej modyfikacji ze względu na coś wobec niego zewnętrznego.

Po drugie, i to interesuje mnie tu szczególnie, analogiczne „złudzenie” pojawia się w chwili, gdy zaczynamy mówić o wartościach. To znaczy uważamy między innymi, że wartościom przypisać można ponadczasowość, stabilność i jednoznaczność. Podobna sytuacja wiąże się z porządkiem politycznym, którego wyrazem w dużej mierze jest prawo. Kołakowski dochodzi do wniosku, że ani fundament prawa, ani treści poszczególnych praw nie posiadają koniecznego charakteru ${ }^{8}$.

Fundament prawa jest zazwyczaj wobec prawa zewnętrzny, a treści, nawet jeśli powtarzają się $\mathrm{w}$ wielu kulturach, nie muszą być absolutne. Innymi słowy nie dadzą się wywnioskować

\footnotetext{
${ }^{6}$ L. Kołakowski, Obecność mitu, Wrocław 1994, s. 11.

7 Ibidem, s. 32.

${ }^{8}$ Ibidem, s. 33 i nast.
} 
w ejdetycznym wglądzie, jak chciałaby tego fenomenologia ${ }^{9}$. Z tego Kołakowski wywodzi: „nie mamy racji obstawać przy jakimkolwiek ładzie prawnym powołując się na to, iż wciela on wartości rzeczywiste współżycia, jeśli nie wolno nam odnieść go do mitycznej dziedziny współwartościowań" ${ }^{10}$.

Kołakowski wydaje się złapany w pułapkę przez swój własny sceptyczny oręż:

A jeśli mit jest projekcją wtórną naszego praktycznego zamiaru, która ma zamiar ów ubezpieczyć i usprawiedliwić, to jednak, gdybyśmy byli pewni, że jest taką projekcją, nie umielibyśmy go przyjąć. Z chwilą, gdy o tym wiemy lub sądzimy, że wiemy, nasze prawo głosu i nasze prawo nadawaniu sensu zdarzeniom zostają nam odjęte. Stąd historia faktyczna wymaga mitu, stąd filozofia rodzi mit, stąd nie mamy prawa uznać się w pełni za twórców mitu, lecz raczej za jego co-chwilowych odkrywców ${ }^{11}$.

Trudno ustrzec się przed mitem przy założeniu, że każdy moment poznawczy jest zapośredniczony, a każdy sąd tylko marną opinią. Kołakowski wygłasza przy tym pogląd o przygodnym charakterze wielu zjawisk społecznych, tak jak wspomniane prawo. W ściśle filozoficznym sensie trudno się z Kołakowskim nie zgodzić, przynajmniej w tym, że wartości i ich prawne wyrażenie jawią się jako konieczne i absolutne, a takimi nie są. Jednak jego postawa prowadzi w efekcie do rezygnacji z rozumu w imię transcendencji, co samo może być zadaniem w istocie krytycznym i demaskatorskim. Jednakże skutkiem takiego postawienia sprawy będzie nie tylko krytyka na przykład prawa naturalnego w obrębie jakiejś rozumności, ale jego dowartościowanie w porządku irracjonalnym, transcendentnym.

Cóż zatem z tego, co mówi Kołakowski, jest dla mnie istotne? Po pierwsze, wychodzi z założenia, że krytyka racjonalności albo

${ }^{9}$ Dobrym przykładem prób tego rodzaju jest: A. Reinach, Aprioryczne podstawy prawa cywilnego, przeł. T. Bekrycht, Warszawa 2011.

${ }^{10}$ L. Kołakowski, op. cit., s. 36.

11 Ibidem, s. 39. 
raczej przyzwyczajeń i przekonań dotyczących poznania i wartości opiera się przede wszystkim na wprowadzeniu pojęcia mitu. $\mathrm{W}$ ten sposób staje się on tożsamy z wszelkimi dotychczasowymi fałszywymi przeświadczeniami ludzkości, które w pierwszym rzędzie dotyczą pewności poznania i istnienia wartości ${ }^{12}$. Po drugie, wiąże tę krytykę z pojęciem prawa, to jest z zasadniczym problemem, jak istnienie prawa wyjaśnić i wytłumaczyć jego dalsze trwanie. Filozofia prawa jako część filozofii i jako samodzielna dziedzina ${ }^{13}$ zajmuje się tą kwestią w sposób różnorodny ${ }^{14}$. Dość powiedzieć, że przy pewnych założeniach definicja prawa ma charakter błędnego koła, to znaczy nie da się prawa wyjaśnić inaczej niż przez odniesienie do takich pojęć, jak legalność, sprawiedliwość czy prawomocność. A one, jak można się domyślić, presuponują zrozumiałość terminu „,prawo”. W pojęciu prawa muszą istnieć zatem inne elementy, by ono obowiązywało; wskazywać tu można na wiarę, przemoc, władzę. To jednak redukuje prawo do relacji, które nie pozwalają na pełne wyjaśnienie tego zjawiska: bo jak pogodzić leżącą u podstaw przemoc ze sprawiedliwością jako celem ${ }^{15}$ ?

Kłopoty z definiowaniem prawa rozszerzyć można również o dylemat, na który zwrócił uwagę Ernst-Wolfgang Böckenförde:

[L]iberalne, zsekularyzowane państwo ma podstawę w czymś, czego samo nie może zagwarantować. (...) Państwo może istnieć jako państwo

${ }^{12}$ Jeśli jest to uprawnione, to można taką strategię, krytykującą racjonalność poznania i podkreślającą relatywizm wartościowania, znaleźć u wielu dwudziestowiecznych myślicieli, poczynając od Freuda i Nietzschego, żyjących jeszcze w wieku wcześniejszym, przez teorię krytyczną szkoły frankfurckiej, aż po filozofię strukturalistyczną i poststrukturalistyczną Foucaulta czy Derridy. W tym względzie krytyczną rolę przejawia nawet fenomenologia Husserla, która jednak nadal przyjmuje prymat czystej świadomości nad innymi zjawiskami. Zob. P. Pieniążek, Suwerenność a nowoczesność. Z dziejów poststrukturalistycznej recepcji myśli Nietzschego, Wrocław 2009, s. 16-22.

${ }^{13}$ Przede wszystkim w ramach pozytywizmu prawnego.

${ }^{14}$ Zob. M. Zirk-Sadowski, Wprowadzenie do filozofii prawa, Kraków 2000.

${ }^{15} \mathrm{Na}$ aporetyczność prawa w taki sposób zwracał uwagę Derrida. Zob. J. Derrida, Force de loi. Le „Fondement mystique de l'autorité”, Paryż 1994, s. 37-38. 
liberalne dzięki temu, że wolność, którą zapewnia obywatelom, będzie regulowana od wewnątrz, z racji moralnej substancji jednostki i jedności społeczeństwa. Z drugiej strony, państwo nie może zagwarantować istnienia tejże substancji moralnej środkami przymusu prawnego i autorytatywnego nakazu; nie może tego uczynić bez rezygnacji ze swojego liberalizmu $(\ldots)^{16}$.

Liberalne demokracje stają przed problemem. Z jednej strony, chcą zrezygnować z ujmowania prawa w taki sposób, który angażowałby transcendencję, na przykład w formie prawa Króla, którego władza uświęcona jest kontekstem religijnym jej nadawania. Jego rolę przejmują organy prawodawcze i konstytucja, gdzie te pierwsze stanowią prawo ze względu na drugą $\mathrm{i}$ w zgodzie $\mathrm{z}$ jej założeniami. Z drugiej strony, liberalizm nie potrafi odnaleźć żadnego stałego gruntu $\mathrm{w}$ ramach swych własnych instytucji, który pozwoliłby uzyskać podobny do boskiego efekt normatywnej skuteczności prawa - o ile państwo liberalne nie powinno opierać się na przemocy i terrorze.

Do podobnych wniosków dochodzi Pierre Legendre ${ }^{17}$, francuski prawnik, specjalista w zakresie historii francuskiego prawa administracyjnego, prawa rzymskiego i kanonicznego. Jego prace opisać można jako „dość dziwną mieszankę psychoanalizy Lacana, prawa rzymskiego, cezaropapizmu i kultu państwa"18. Z tej charakterystyki wyłania się już pewien obraz. Legendre, jak Böckenförde, obawia się, że zapominanie o, powiedzmy, mitycznym (w jego wypadku psychoanalitycznym) wymiarze prawa prowadzić może

${ }^{16}$ E.-W. Böckenförde, Wolność-państwo-Kościót, przeł. P. Kaczorowski, Kraków 1994, s. 120.

17 Popularność myśli Pierre’a Legendre’a w Polsce jest raczej marginalna. Poświęcono mu numer „Kronosa” 3/2010 i przetłumaczono jedną jego książkę, cytowaną zresztą w niniejszym artykule. O Legendrze pisali też T. Chauvin (Prawo jako dyskurs o życiu - antropologia dogmatyczna Pierre'a Legendre'a, „Archiwum Filozofii Prawa i Filozofii Społecznej" 2013, t. 2, s. 5-24) i A. Sulikowski (Konstytucjonalizm a nowoczesność. Dyskurs konstytucyjny wobec tryumfu i kryzysu moderny, Wrocław 2012, s. 210-211).

18 B. Latour, Fabrication du droit, Paryż 2004, s. 291 (tłum. własne). 
do upadku jednostki i w konsekwencji całego państwa. Jak to tłumaczy?

Zacznę od tego, że Legendre proponuje rozwijanie nowej nauki, którą nazywa antropologią dogmatyczną ${ }^{19}$. Jak twierdzi, byłaby to antropologia, która zwraca uwagę na ignorowany do tej pory „wymiar instytucjonalności”20. Prace Legendre'a dotyczą bardzo różnej tematyki, ale łączy je przywiązanie do pojęć czy problemów, które nadają im względną jedność i określają właśnie ten instytucjonalny aspekt zjawisk. Chodzi tu w pierwszym rzędzie o prawo, język, życie jako zjawisko biologiczne i społeczne, tworzenie się podmiotu i istnienie Państwa. Każdy z tych obszarów badań ma dla Legendre'a nieusuwalny wymiar normatywny ${ }^{21}$. Są one ze sobą powiązane tak silnie, że analityczne ich rozdzielenie, przynajmniej w tej myśli, jest zadaniem trudnym. Stąd Legendre często się powtarza i mnoży określenia dotyczące tego samego.

Przykładem takiego powtarzania się jest zasadnicza teza antropologii dogmatycznej o istnieniu Odniesienia (la Référence). W kontekście oznacza ono prawodawcę, uogólnionego do figury Kapłana $^{22}$ (le Pontife), pustego miejsca, które przyjąć może różne ucieleśnienia, ale zawsze powraca do pewnej figury „logicznej”. Owa logika byłaby koniecznością, ale wynikającą znów z pewnego zastanego porządku, którego nie sposób objąć w całości. Przyznaje się mu racjonalność w figurze Rozumu, którego zrozumienie i przełożenie na praktykę stanowi zadanie prawników ${ }^{23}$.

Ze względu na „logiczność”, konieczność przyjęcia takiej formuły Legendre mówi również o „logice Trzeciego (la logique du

${ }^{19}$ P. Legendre, De la Société comme Texte. Linéaments d'une anthropologie dogmatique, Paryż 2001.

${ }^{20}$ Idem, Sur la question dogmatique en Occident, Paryż 1999, s. 233.

${ }^{21}$ Idem, De la Société..., s. 10.

${ }^{22}$ Idem, L'amour du censeur. Essai sur l'ordre dogmatique, Paryż 1974, s. 66.

${ }^{23}$ Idem, Sur la question..., s. 220. 
Tiers)”24, „społecznym Hermesie”25, „Ojcu” ${ }^{26}$. Każde z tych określeń wyrasta $\mathrm{z}$ innego porządku: Trzeci jest formą transcendentalną, pojęciem najogólniejszym, Hermes odnosi się do komunikacji, Ojciec - do związków genealogicznych i filiacji. Istnienie takiej „pustej formy” czy „pustego miejsca” ${ }^{27}$ ma, ze względu na swe psychoanalityczne wyjaśnienie ${ }^{28}$, znaczenie dla prawidłowego rozwoju psychicznego człowieka. „Prawidłowy rozwój psychiczny” to ukonstytuowanie się podmiotu, a elementy owej konstytucji zbadać powinna antropologia dogmatyczna. Jednym z tych elementów będzie pojęcie granicy, oddzielenia od Matki, od Ojca, od samego siebie w przypadku bycia winnym. Ma to na celu nie tylko zdrowie, ale też zachowanie porządku w państwie, o który tak bardzo martwi się Böckenförde - porządek zapewni „miłość do cenzora” ${ }^{29}$.

Oczywiście choćby ze względu na liczbę wydanych przez Legendre'a prac - jest ich ponad dwadzieścia - rozwija on różne wątki, co nie zmienia przedstawionego tu schematu. Ten schemat, logika czy struktura, bo tak też to bywa określane, ma charakter uniwersalny: „,chodzi o] obraz Ojca (przez duże 0) ludzkości - bez względu na to, o jaką ludzkość chodzi i z jaką kulturową wersją tego obrazu mamy do czynienia" ${ }^{30}$. Ponadto znajduje on

${ }^{24}$ Idem, De la Société..., s. 152; idem, Zbrodnia kaprala Lortiego. Traktat o Ojcu, przeł. A. Dwulit, Warszawa 2011, s. 71. Logique du tiers jest też określeniem, które można przetłumaczyć jako logika wielowartościowa (logika akceptująca wartość „trzecią”, czyli jeszcze jedną prócz prawdy i fałszu).

${ }^{25}$ Idem, Sur la question..., s. 26.

${ }^{26}$ Idem, Zbrodnia..., s. 35.

${ }^{27}$ Idem, De la Société..., s. 152.

${ }^{28}$ Legendre odwołuje się wielokrotnie do wyśnionej przypowieści Freuda z Totemu i tabu, opowiadającej o zabójstwie ojca-prawodawcy przez synów zazdrosnych o jego żony. Po zbrodni synowie odczuwali skruchę i winę, a uczucie zazdrości nie zniknęło. Dlatego zdecydowali o powołaniu „zakazu” (Freud mówi o kazirodztwie), którego gwarantem był totem (zmarły ojciec). Zob. S. Freud, Totem i tabu. Kilka zgodności w życiu psychicznym dzikich i neurotyków, przeł. M. Poręba, R. Reszke, [w:] idem, Pisma społeczne, Warszawa 1998, s. 360-362.

${ }^{29}$ P. Legendre, L'amour..., s. 5-7.

${ }^{30}$ Idem, Zbrodnia..., s. 35. 
interdyscyplinarne zastosowanie (tak np. w estetyce, jak w nauce o tańcu ${ }^{31}$ ), przy założeniu, że we wszystkich zjawiskach kultury przejawia się jakiegoś rodzaju normatywność zaklęta w dogmacie. Prawo jest dogmatem par excellence, więc pośrednio zawsze stanowi przedmiot badań.

Z drugiej strony, jeśli przyjmiemy ten schemat w stosunku do prawa samego, to okaże się, że Odniesienie nie posiada żadnego wytłumaczenia w prawie. Prawo pisane, prawo w praktyce, historia prawa jest jedynie znaczącym Rozumu, będącego jednym z aspektów Odniesienia. To nieświadomość jest siłą określającą treść prawa i ów schemat „logiki Trzeciego”. Nieświadomość z kolei przejawia się poprzez symbole, znaki, mity, obrazy ${ }^{32}$. Zatem w samym jądrze prawa mamy do czynienia z pewną dialektyką mitu i rozumu, walką między świadomością a nieświadomością, która rozgrywa się na poziomie ponadpodmiotowym: w historii pomiędzy instytucjami (pojęciami).

Dlatego też Jacques Lenoble i François Ost oparli swoją strategię intelektualną na koncepcji Pierre'a Legendre’a. W monumentalnym dziele Droit, mythe et raison ${ }^{33}$ za dobrą monetę wzięli uwagę poczynioną przez Paula Ricoeura w Le conflit des interprétations:

[M]etafora prawnicza wyraża elementy ludzkiego doświadczenia o najwyższym stopniu zracjonalizowania; nic innego nie posiada tyle jasności, rygoru, historycznej stałości, co praktyki prawne (...); mitologia prawa ma tę przewagę nad każdą inną, że jest „mitologiką” ${ }^{34}$.

Dalej dodaje:

[Jest to mitologia - M.L.] najbardziej ograniczona, ze wszystkich mitologii najbardziej złudna i dlatego najtrudniejsza do zdekonstruowania,

31 Zob. idem, La passion d'être un autre. Étude pour la danse, Paryż 1974.

${ }^{32}$ Idem, Sur la question..., s. 70.

${ }^{33}$ J. Lenoble, F. Ost, Droit, mythe et raison : essai sur la dérive mythologique de la rationalité juridique, Bruksela 1980 (tłum. własne).

${ }^{34}$ P. Ricoeur, Le conflit des interprétations. Essais d'herméneutique, Paryż 2013, s. 492 (tł. własne). 
lecz przede wszystkim taka, która najmocniej stawia opór przeinterpretowaniu ${ }^{35}$.

Lenoble i Ost uznali, że ta dwoistość prawa stanowi ciekawą hipotezę i przyjęli z tego powodu pewien sposób postępowania, który według nich opisać można jako spiralę ${ }^{36}$. Rozpoczynając od zewnętrznego kręgu, kiedy mitologia prawa oznacza wyłanianie się pewnych mitów, w które prawnicy wierzą (np. w racjonalnego prawodawcę), poprzez obszar środkowy, będący krytyką mitów opartą na logice zwanej prawniczą, aż do samego środka, mitycznego jądra prawa. Legendre sytuuje się tu w przejściu między obszarem drugim a trzecim, wyznacza dla badań kierunek. Lenoble i Ost uznają Legendre'a za krytyka tradycyjnych poglądów na prawo, co nie ulega wątpliwości. Jednocześnie dla autorów tych Legendre wskazuje na nowy obszar, to znaczy wymykający się logicyzmowi, ale posiadający $\mathrm{w}$ ich opinii walor racjonalności. W ten sposób realizuje on założenie o mito-logice.

Teza o Odniesieniu służyć im będzie do wskazania słabości, to jest mitycznych residuów w dziełach myślicieli, których koncepcje wpłynęły znacząco na współczesną naukę o prawie: Arystotelesa, Kanta i Hansa Kelsena. W sprawie argumentacji odsyłam czytelnika do książki, bo jest to rzecz godna uwagi. Podam jedynie przykład, dotyczący ostatniego z analizowanych filozofów.

Hans Kelsen w ramach swojej transcendentalnej filozofii prawa uznał, że konieczne jest przyjęcie istnienia Grundnorm, normy podstawowej. Nie posiada ona $\mathrm{w}$ tym ani żadnym praktycznym systemie jakiejkolwiek treści, nie przesądza o treści innych norm, jest jedynie koniecznością transcendentalną, niezbędną Kelsenowi do zagwarantowania możliwości poznania prawa, to jest innych norm $^{37}$. Lenoble i Ost rekonstruują różne aspekty tego założenia

\footnotetext{
${ }^{35}$ Ibidem, s. 492-493.

36 J. Lenoble, F. Ost, op. cit., s. 10.

${ }^{37}$ M. Zirk-Sadowski, op. cit., s. 51.
} 
i dochodzą do wniosku, że posiada ten sam sens, co Odniesienie u Legendre'a. Przytaczają inną opinię, która odwołuje się wprost do psychoanalizy lacanowskiej i określa Grundnorm „imieniem ojca"38.

Jednakże to, co dla Kelsena jest formalnym założeniem, dla Legendre’a jest formą wyjaśnienia, bo, jak pokazałem, ostatecznie odnosi się do tezy o istnieniu nieświadomości. Co więcej, Legendre podkreśla, że logika Trzeciego ma charakter uniwersalny i obejmuje również inne sfery, na przykład biologiczną (reprodukcyjną i genealogiczną), której poświęcił większą część Zbrodni kaprala Lortiego (Legendre atakuje koncepcję związków partnerskich ${ }^{39}$ ze względu na ich niezgodność z logiką Trzeciego).

Biorąc pod uwage postawę ideologiczną Legendre'a, jego teoria jest trudna do przyjęcia. Jednak sama niechęć do poglądów nie powoduje, że są one fałszywe czy choćby wątpliwe. Dlatego konieczne byłoby podważenie podstaw jego myśli.

Legendre opiera swą koncepcję na tezach psychoanalitycznych. O ile sama hipoteza o istnieniu nieświadomości może być interpretowana w różny, również filozoficzny sposób ${ }^{40}$, to nie można jej utrzymać jako teorii naukowej. I nawet jeśli obronimy filozoficznie tezy Freuda, uznając je za swoistą metapsychologię, to jego pisma etnologiczne zostały wielorako zdyskredytowane ${ }^{41}$. Uroszczenia Legendre'a opierają się w zasadniczym stopniu na tych Freudowskich ustaleniach, co, jak sądzę, skutecznie je unieważnia. Nawet gdyby dało się wnioski z Totemu i tabu jednak obronić, to Legendre wikła się w dodatkowy problem. Mianowicie postuluje on autonomiczność dyskursu prawnego, sprzeciwia się jego

38 J. Lenoble, F. Ost, op. cit., s. 542.

${ }^{39}$ B. Perreau, Faut-il brûler Legendre, la fable du péril symbolique et de la police familiale, „Vacarme”, nr 25, http://www.vacarme.org/article1640.html (data dostępu: 10.05.2015).

40 Zob. A. Leder, Nauka Freuda w epoce „Sein und Zeit”, Warszawa 2007.

41 Tutaj choćby G. Durand, op. cit., s. 55-61. 
scjentyfikacji ${ }^{42}$, sam natomiast wprowadza inny, zresztą naturalistyczny grunt dla nauk prawnych. A poza przekonaniem o źródłowej zbieżności prawa i nieświadomości, Legendre nie ma nic innego w zanadrzu, by ten zabieg wyjaśnić.

Koncepcja Legendre'a dotyka również ogólniejszych problemów filozofii, przede wszystkim zgody bądź nie na transcendencję. Samo pojęcie transcendencji ${ }^{43}$ oznaczać może różne rzeczy, ale w pierwszej kolejności transcendencja zakłada istnienie obszaru rzeczywistości, który nie poddaje się doświadczeniu, poznaniu, zrozumieniu. Ten obszar niepewności mogą zaludniać bardzo różne byty, jak bogowie, jednorożce, ale też dobro i sprawiedliwość w ich idealnej wersji. Filozofia może sobie pozwolić - ba!, jest to jej zadaniem - na to, by uchwycić pojęcia przy zachowaniu całej chaotyczności podłoża, z którego się wyłoniły ${ }^{44}$. Nie oznacza to jednak kapitulacji rozumu wobec zjawisk niezrozumiałych czy nadmiernie skomplikowanych. I nie chodzi tu o podłoże instytucjonalne, na przykład teologiczne, bo sama historyczna proweniencja pojęcia nie przesądza o jego rozumieniu ${ }^{45}$.

\section{Bibliografia}

Böckenförde E.-W., Wolność - państwo - Kościót, przeł. P. Kaczorowski, Kraków 1994.

Canguilhem G., Études d'histoire et de philosophie des sciences, Paris 1994.

Deleuze G., Guattari F., Co to jest filozofia?, przeł. P. Pieniążek, Gdańsk 2000.

Derrida J., Force de loi. Le „Fondement mystique de l'autorité”, Paris 1994.

Durand G., Wyobraźnia symboliczna, przeł. C. Rowiński, Warszawa 1986.

Freud S., Totem i tabu. Kilka zgodności w życiu psychicznym dzikich i neurotyków, przeł. M. Poręba, R. Reszke, [w:] idem, Pisma społeczne, Warszawa 1998.

${ }^{42}$ P. Legendre, Sur la question..., s. 229, 233.

43 Przynajmniej w radykalnej wersji. Na myśli mam niepoznawalność innego bytu lub odrębność bytów duchowych od materialnych. Zob. Leksykon filozofii klasycznej, red. J. Herbut, Lublin 1997, hasło: transcendencja.

${ }^{44}$ G. Deleuze, F. Guattari, op. cit., s. 51.

${ }^{45}$ G. Canguilhem, Études d'histoire et de philosophie des sciences, Paryż 1994, s. 18. 
Kołakowski L., Obecność mitu, Wrocław 1994.

Latour Bruno, Fabrication du droit, Paryż 2004.

Leder A., Nauka Freuda w epoce „Sein und Zeit”, Warszawa 2007.

Legendre P., L'amour du censeur. Essai sur l'ordre dogmatique, Paris 1974.

Legendre P., Sur la question dogmatique en Occident, Paris 1999.

Legendre P., De la Société comme Texte. Linéaments d'une anthropologie dogmatique, Paris 2001.

Legendre P., Zbrodnia kaprala Lortiego. Traktat o Ojcu, przeł. A. Dwulit, Warszawa 2011.

Leksykon filozofii klasycznej, red. J. Herbut, Lublin 1997.

Lenoble J., Ost F., Droit, mythe et raison : essai sur la dérive mythologique de la rationalité juridique, Bruksela 1980.

Lévi-Strauss C., Antropologia strukturalna, przeł. K. Pomian, Warszawa 2000.

Perreau B., Faut-il brûler Legendre, la fable du péril symbolique et de la police familiale, „Vacarme”, nr 25, http://www.vacarme.org/article1640.html (data dostępu: 10.05.2015).

Pieniążek P., Suwerenność a nowoczesność. Z dziejów poststrukturalistycznej recepcji myśli Nietzschego, Wrocław 2009.

Ricoeur P., Le conflit des interprétations. Essais d'herméneutique, Paryż 2013.

Zirk-Sadowski M., Wprowadzenie do filozofii prawa, Kraków 2000. 